Implementing Flexible Manufacturing Systems 
Other Macmillan titles of related interest

R. Anderson, Management, Information Systems and Computers

J. D. Radford and D. B. Richardson, The Management of Manufacturing Systems

R. Stone, Project Engineering 


\section{Implementing Flexible \\ Manufacturing Systems}

Nigel R. Greenwood

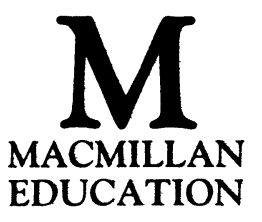


(c) Nigel R. Greenwood 1988

Softcover reprint of the hardcover 1st edition 1988 978-0-333-39156-3

All rights reserved. No reproduction, copy or transmission of this publication may be made without written permission.

No paragraph of this publication may be reproduced, copied or transmitted save with written permission or in accordance with the provisions of the Copyright Act 1956 (as amended), or under the terms of any licence permitting limited copying issued by the Copyright Licensing Agency, 33-4 Alfred Place, London WC1E 7DP.

Any person who does any unauthorised act in relation to this publication may be liable to criminal prosecution and civil claims for damages.

First published 1988

Published by

MACMILLAN EDUCATION LTD

Houndmills, Basingstoke, Hampshire RG21 2XS

and London

Companies and representatives

throughout the world

British Library Cataloguing in Publication Data

Greenwood, Nigel R.

Implementing flexible manufacturing

systems.

1. Flexible manufacturing systems

I. Title

$658.5^{\prime} 14 \quad$ TS155.6

ISBN 978-1-349-07961-2 ISBN 978-1-349-07959-9 (eBook)

DOI 10.1007/978-1-349-07959-9 
To my mother, and in fond memory of my father 


\section{Contents}

Foreword $x i$

Preface xii

Acknowledgements xiv

1 An Introduction to Flexible Manufacturing 1

1.1 What is flexible manufacturing? 1

1.2 The origins of flexible manufacturing 1

1.3 The development of FMS 4

1.4 Group Technology 8

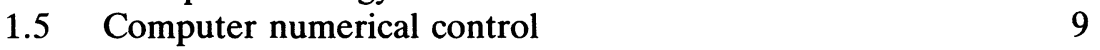

1.6 The history of FMS 10

1.7 FMS today 12

1.8 The constituents of FMS 15

1.9 Classifying FMS 18

1.10 Why implement FMS? 22

2 Some Examples of Flexible Manufacturing 24

2.1 Introduction 24

2.2 The SCAMP flexible manufacturing system 24

2.3 Vought Aero Products Division FMS 34

2.4 FMS within General Electric (USA) 38

2.5 FMS at Fanuc 45

2.6 Examples of sophisticated automation systems 48

2.7 Concluding comments 52

3 Project Structure and Management 55

3.1 Introduction 55

3.2 Germination of an idea 56

3.3 The content of the Conceptual Design 57

3.4 Implementing the Conceptual Design 60

3.5 The Project Team 64

3.6 Detailed Design of the FMS 66 
$\begin{array}{lll}3.7 & \text { Design Reviews } & 71\end{array}$

$\begin{array}{lll}3.8 & \text { Project timescales } & 73\end{array}$

$\begin{array}{lll}3.9 & \text { Project budgeting and workloads } & 77\end{array}$

4 The Components $\quad 81$

$\begin{array}{lll}4.1 & \text { Introduction } & 81\end{array}$

4.2 The importance of the components selected 81

$\begin{array}{lll}4.3 & \text { A place to start } & 82\end{array}$

$\begin{array}{lll}4.4 & \text { Selecting the components } & 83\end{array}$

4.5 Consequential system implications $\quad 85$

$\begin{array}{lll}4.6 & \text { Some strategic issues } & 86\end{array}$

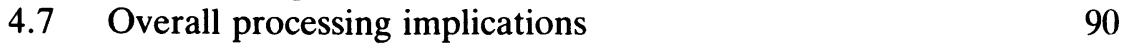

4.8 Concluding comments 91

5 The Processes $\quad 93$

$\begin{array}{lll}5.1 & \text { Introduction } & 93\end{array}$

$\begin{array}{lll}5.2 & \text { The initial analysis } & 93\end{array}$

$\begin{array}{lll}5.3 & \text { Collecting the data } & 94\end{array}$

$\begin{array}{lll}5.4 & \text { Equipment requirements } & 96\end{array}$

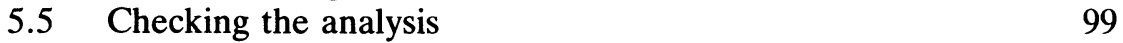

$\begin{array}{lll}5.6 & \text { Equipment utilisation } & 101\end{array}$

$\begin{array}{lll}5.7 & \text { Ancillary equipment } & 103\end{array}$

$\begin{array}{lll}5.8 & \text { Inspection equipment } & 107\end{array}$

$\begin{array}{ll}5.9 \text { Control of the process } & 109\end{array}$

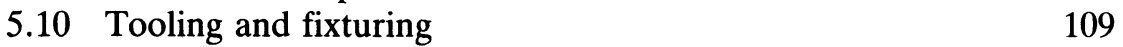

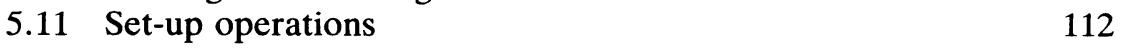

$\begin{array}{ll}5.12 \text { Concluding comments } & 113\end{array}$

6 Material Handling $\quad 116$

$\begin{array}{lll}6.1 & \text { Introduction } & 116\end{array}$

$\begin{array}{ll}6.2 \text { Types of material handling needs } & 116\end{array}$

6.3 Automated Guided Vehicle Systems 119

$\begin{array}{lll}6.4 & \text { Conveyors } & 122\end{array}$

$\begin{array}{ll}6.5 & \text { Rail-guided transfer mechanisms } \\ & 123\end{array}$

$\begin{array}{lll}6.6 & \text { Robots } & 124\end{array}$

$\begin{array}{lll}6.7 & \text { Gantry loaders } & 128\end{array}$

$\begin{array}{ll}\text { 6.8 Manual material handling } & 128\end{array}$

$\begin{array}{lll}6.9 & \text { Buffer stores } & 130\end{array}$

6.10 Selecting the correct material handling systems 133

$\begin{array}{ll}6.11 \text { Concluding comments } & 135\end{array}$

7 Computer Simulation $\quad 139$

7.1 Introduction 139

$\begin{array}{ll}7.2 & \text { Simulation for FMS design } \\ \end{array}$ 
7.3 Microcomputer-based simulation systems 143

7.4 The 'Modelmaster' simulation package 145

7.5 How and when computer simulation should be used 153

7.6 Concluding comments 156

8 Computer Control Systems 158

8.1 Introduction 158

8.2 Some background 158

8.3 Objectives of the FMS control system 162

8.4 General software requirements 165

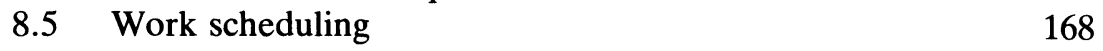

8.6 Status monitoring and control 171

8.7 Contingency management 174

8.8 Computer system back-up 177

$\begin{array}{lll}8.9 \text { Statistics } & 179\end{array}$

8.10 General considerations $\quad 180$

8.11 Concluding comments 183

9 Communications 184

9.1 Introduction 184

9.2 FMS communications requirements 184

9.3 Workstation-oriented communications 186

9.4 Some implications of standby computers 193

9.5 Communications with remote computers 196

9.6 FMS communications architectures 197

9.7 Concluding comments 201

10 Financial Justification $\quad 202$

$\begin{array}{lll}10.1 & \text { Introduction } & 202\end{array}$

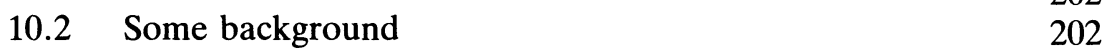

$\begin{array}{lll}10.3 & \text { Some strategic issues } & 203\end{array}$

10.4 Performing the analysis 205

10.5 Preparing for the analysis 212

10.6 Presentation of the results 215

$\begin{array}{ll}10.7 \text { Concluding comments } & 216\end{array}$

11 Installation and Commissioning $\quad 218$

$\begin{array}{lll}11.1 & \text { Introduction } & 218\end{array}$

11.2 Background comments 218

11.3 FMS siting implications 219

11.4 Planning the FMS installation 221

$\begin{array}{ll}11.5 & \text { The working environment } \\ 11.6 & 223\end{array}$

11.6 Installing equipment 224

$\begin{array}{lll}11.7 & \text { Safety equipment } & 225\end{array}$

11.8 Integrating the equipment and the systems 232 
11.9 Training and recruitment

12 Factors Likely to Influence the Development of FMS 237

$\begin{array}{lll}12.1 & \text { Introduction } & 237\end{array}$

$\begin{array}{lll}12.2 & \text { The people } & 238\end{array}$

12.3 Industry-acceptable terms and conditions 240

12.4 Generic FMS control systems 240

$\begin{array}{ll}12.5 & \text { Single-source co-ordination } \\ 12.6 & 243\end{array}$

$\begin{array}{lll}12.6 & \text { Communications } & 246\end{array}$

12.7 Robot technology 249

$\begin{array}{lll}12.8 & \text { Expert systems } & 251\end{array}$

$\begin{array}{lll}12.9 & \text { Manufacturing processes } & 254\end{array}$

12.10 Computer Integrated Manufacturing 258

References and Recommended Reading 264

$\begin{array}{ll}\text { Glossary of Terms } & 273\end{array}$

$\begin{array}{ll}\text { Index } & 277\end{array}$ 


\section{Foreword}

All too occasionally an internationally regarded expert finds the time and motivation to fill a glaring gap in the texts written on his subject. The author must be very highly committed to his task, since the effort involved is substantial and brings an additional 'avoidable' workload to an already busy lifestyle.

I believe we are fortunate in that this book is the product of such a rare event.

The subject of Flexible Manufacturing Systems (FMS) could not be more apposite to the future of manufacturing industry. FMS theory and practice is in my view quite simply the single most generic and practicable perspective from which to view the next two decades of manufacturing systems development. Despite its central importance, however, the subject has not seen the adequate publication of much needed quality texts.

Perhaps the particular breadth and depth of understanding required to write convincingly in this area has deterred otherwise eager technical journalists. Whatever the reason for the dearth of quality books on FMS, I am delighted to see this thoughtfully prepared volume arriving to fill the void. The successive chapters deal evenly and objectively with concepts, pros and cons, and go on to provide an excellent narrative of guidance for system designers and implementors, as well as those charged with relevant management decision-making.

Dr Greenwood's text clearly contains much of his accumulated knowledge on the subject of FMS and is immediately recognisable as an authoritative statement. I hope and believe that the distinction will not prevent the book from gaining the very wide audience that it and the subject of FMS truly deserve.

Keith Rathmill 


\section{Preface}

The purpose of this book is to provide both an introduction to the concept of flexible manufacturing and guidance for those embarking on, or considering embarking on, the implementation of such a project.

It should be appreciated that this book is about manufacturing strategies, rather than automation. It is not an attempt to answer all the questions likely to confront the enthusiastic FMS designer. This would be too bold an objective. Instead it is an attempt to raise the major issues. There is much expertise and literature available to answer application-specific questions, and a comprehensive bibliography is included in References and Recommended Reading at the end of the book.

The firm belief of the author is that flexible manufacturing systems, in one form or another, represent how the majority of manufacturing will be carried out in the future. Soon, a production engineer will not be considered experienced without some exposure to FMS. However, while technology has advanced to the point where the technical risks associated with FMS have been substantially reduced, it is still not easy to implement such systems successfully. This is due to the influence of a variety of factors, many of which are discussed.

It is hoped that through this book the reader will be led to consider issues which might otherwise have been overlooked. The potential benefits which can be reaped as a result of implementing an FMS successfully are immense. However, when embarking on an FMS project, one should not:

(1) Underestimate the long-term impact of installing the system.

(2) Underestimate the difficulty of finding the right people and technology to implement the system successfully.

(3) Underestimate the training and safety implications.

(4) Be constrained by traditional approaches to manufacturing when designing the system.

(5) Underestimate the amount of work.

(6) Be hasty in choosing one's consultants and suppliers. 
It has been said that life is not really full of problems, merely challenges. If this is the case, then FMS is one of the most exciting and potentially rewarding challenges facing manufacturing system engineers.

I hope that both managers and students interested in flexible manufacturing will find this book of value, not necessarily because it answers all the questions, but because it is a legitimate attempt to raise what generally appear to be the most important questions.

Nigel R. Greenwood 


\section{Acknowledgements}

This text would not be complete without an expression of my gratitude to the following people and organisations whose generous help made this book possible:

Gordon Mackie

Bernard Carey

Mel Chudzik

Andrea Hill

Mike Jeffries

Ralph Patsfall

Prakash Rao

Keith Rathmill

Sir Jack Wellings
Deckel Machine Tools GMBH

Fanuc Ltd

Frost and Sullivan

General Electric Company (USA)

Eaton-Kenway Inc.

LTV Aerospace \& Defence Company

Scamp Systems Ltd

S.N.E.C.M.A.

Okuma Machinery Ltd

Werner Kolb

Not forgetting Macmillan Education for their seemingly endless patience. 